\title{
Phosphorus fertilisation under nitrogen limitation can deplete soil carbon stocks: evidence from Swedish meta-replicated long-term field experiments
}

\author{
Christopher Poeplau $^{1,3}$, Martin A. Bolinder ${ }^{1}$, Holger Kirchmann ${ }^{2}$, and Thomas Kätterer ${ }^{1}$ \\ ${ }^{1}$ Swedish University of Agricultural Sciences (SLU), Department of Ecology, Box 7044, 75007 Uppsala, Sweden \\ ${ }^{2}$ Swedish University of Agricultural Sciences (SLU), Department of Soil and Environment, Box 7014, 75007 Uppsala, \\ Sweden \\ ${ }^{3}$ Thuenen-Institute of Climate Smart Agriculture, Bundesallee 50, 38116 Braunschweig, Germany
}

Correspondence to: Christopher Poeplau (christopher.poeplau@ti.bund.de)

Received: 8 September 2015 - Published in Biogeosciences Discuss.: 12 October 2015

Revised: 1 February 2016 - Accepted: 5 February 2016 - Published: 24 February 2016

\begin{abstract}
Increasing soil organic carbon (SOC) in agricultural soils can mitigate atmospheric $\mathrm{CO}_{2}$ concentration and also contribute to increased soil fertility and ecosystem resilience. The role of major nutrients in SOC dynamics is complex, due to simultaneous effects on net primary productivity (NPP) that influence crop residue carbon inputs and in the rate of heterotrophic respiration (carbon outputs). This study investigated the effect on SOC stocks of three different levels of phosphorus and potassium (PK) fertilisation rates in the absence of nitrogen fertilisation and of three different levels of nitrogen fertiliser in the absence of PK fertiliser. This was done by analysing data from 10 metareplicated Swedish long-term field experiments ( $>45$ years). With $\mathrm{N}$ fertilisation, SOC stocks followed yield increases. However, for all PK levels, we found average SOC losses ranging from $-0.04 \pm 0.09 \mathrm{Mg} \mathrm{ha}^{-1} \mathrm{yr}^{-1}$ (ns) for the lowest to $-0.09 \pm 0.07 \mathrm{Mg} \mathrm{ha}^{-1} \mathrm{yr}^{-1}$ ( $p=0.008$ ) for the highest application rate, while crop yields as a proxy for carbon input increased significantly with PK fertilisation by 1,10 and $15 \%$. We conclude that SOC dynamics are mainly outputdriven in the PK-fertilised regime but mostly input-driven in the $\mathrm{N}$-fertilised regime, due to the much more pronounced response of NPP to N than to PK fertilisation. It has been established that $\mathrm{P}$ rather than $\mathrm{K}$ is the element affecting ecosystem carbon fluxes, where $\mathrm{P}$ fertilisation has been shown to (i) stimulate heterotrophic respiration, (ii) reduce the abundance of arbuscular mycorrhizal fungi and (iii) decrease the crop root: shoot ratio, leading to higher root-derived carbon input.
\end{abstract}

The higher export of $\mathrm{N}$ in the PK-fertilised plots in this study could (iv) have led to increased $\mathrm{N}$ mining and thus mineralisation of organic matter. More integrated experiments are needed to gain a better understanding of the relative importance of each of the above-mentioned mechanisms leading to SOC losses after $\mathrm{P}$ addition.

\section{Introduction}

Maintaining or increasing soil organic carbon (SOC) stocks in agricultural soil is important for ecosystem resilience, soil fertility and sustainable crop production. Sequestration of SOC is also an important climate mitigation option (Lal, 2003; Lugato et al., 2006). The annual export of plant biomass demands a sufficient nutrient supply, mainly of nitrogen $(\mathrm{N})$, phosphorus $(\mathrm{P})$ and potassium $(\mathrm{K})$. To cope with steadily increasing global food demand and limitations to spatial expansion of agricultural area, the optimal balance between production and sustaining soil fertility has to be found. The magnitude and dynamics of SOC stocks are determined by the ratio between inputs and outputs of carbon. It is a well-established fact that mineral (NPK) fertiliser has a strong positive effect on net primary production (NPP) and thus on carbon inputs (Kätterer et al., 2012). In three global meta-analyses, the increase in topsoil SOC following mineral nitrogen fertilisation was reported to range from 3.5 to $8 \%$ (Alvarez, 2005; Ladha et al., 2011; Lu et al., 2011). 
Mineral fertilisation is therefore generally recommended as a suitable management practice for SOC sequestration ( $\mathrm{Lu}-$ gato et al., 2006). In many long-term experiments with differing fertiliser treatments, SOC stocks have been well explained by measured or estimated NPP (Kätterer et al., 2012). However, the effect of $\mathrm{N}$ fertilisation on the corresponding $\mathrm{C}$ output by heterotrophic respiration and the mechanisms involved are still not fully understood. Nitrogen fertilisation has been shown to decrease respiratory $\mathrm{C}$ losses, especially in combination with a labile $\mathrm{C}$ source amendment. This is mostly explained by the " $\mathrm{N}$ mining" theory, which predicts accelerated microbial decomposition of more recalcitrant, energy-poor organic matter in the search for nitrogen under $\mathrm{N}$ deficiency. Energy for this breakdown is thereby derived from labile $\mathrm{C}$, which in turn cannot be used efficiently for biosynthesis (Bradford et al., 2008; Craine et al., 2007; Milcu et al., 2011; Schimel and Weintraub, 2003). Cleveland and Liptzin (2007) reported a globally well-constrained microbial biomass $C: N: P$ ratio of $60: 7: 1$, which indicates stoichiometric constraints for microbial growth. Recently, Murphy et al. (2015) observed that specific N-rich compounds of soil organic matter were primed after glucose addition. This observation can be interpreted as selective $\mathrm{N}$ mining. The opposite effect, i.e. acceleration of $\mathrm{C}$ mineralisation by $\mathrm{N}$ addition, has also been reported (Allen and Schlesinger, 2004; Milcu et al., 2011; Reed et al., 2011), indicating that $\mathrm{N}$ can be a limiting factor for microbial breakdown. To date, studies about the effect of mineral fertiliser on SOC have mainly focused on $\mathrm{N}$ or combined $\mathrm{N}, \mathrm{P}$ and $\mathrm{K}$ fertiliser because nitrogen has the most obvious effects on the carbon cycle and NPK is the most common fertiliser combination used in commercial agriculture. However, it has recently been shown that $\mathrm{P}$ or PK fertilisation can have stimulating effects on heterotrophic respiration (Cleveland and Townsend, 2006; Cleveland et al., 2002; Fisk et al., 2015; Nottingham et al., 2015). These studies were conducted in forest ecosystems, mostly on P-limited tropical soils, and were short-term and biased towards carbon output, since changes in carbon input after fertilisation are more difficult to measure in forest systems and the assessment of net effects on SOC requires longterm observation. The response of SOC to $\mathrm{P}$ and $\mathrm{K}$ fertilisation of arable soils is not well documented, although these elements are considered to be the most important plant nutrients after nitrogen. As such, PK fertiliser application does usually have a positive effect on NPP, which should hypothetically counterbalance eventual losses via increased heterotrophic respiration. "P mining" at the cost of $\mathrm{C}$, as the equivalent of $\mathrm{N}$ mining under P-limited conditions, has not been observed in soils (Craine et al., 2007). The Swedish long-term soil fertility experiments were established between 1957 and 1966 (Carlgren and Mattsson, 2001). These experiments are located across the country and cover a wide range of climatic and pedological conditions. They are unique because all of them have an almost identical experimental design consisting of a combination of different $\mathrm{N}$ and PK lev- els. Due to this meta-replication and the length of the experiments ( $>45$ years), they have provided good opportunities to examine different hypotheses under in situ conditions for several decades (Simonsson et al., 2009; Williams et al., 2013). The effect of PK without $\mathrm{N}$ or $\mathrm{N}$ without PK, as examples for two extremely opposing nutrient regimes, has not been assessed. This comparison has the potential to provide significant insights on long-term nutrient effects on SOC dynamics. The main question asked was how long-term $\mathrm{N}$ fertilisation influenced SOC stocks in the absence of PK fertilisation, and vice versa, and how pedoclimatic factors affected those responses.

\section{Materials and methods}

\subsection{Data set}

The data set covered 10 sites from the ongoing Swedish longterm soil fertility experiments (Table 1), all located in central and southern Sweden (with five sites in each region). A total of 16 combinations of mineral fertiliser applications (NPK), including four different $\mathrm{N}$ levels and four different PK levels, are being compared in two crop rotations (i.e. with or without manure application) with two replicates in a randomised split block design. The $\mathrm{N}$ levels (applied as ammonium nitrate before 1989 and as Nitro-chalk afterwards) are 0, 50, 100 and $200 \mathrm{~kg}$ for the southern Swedish sites and 0, 41, 82, $125 \mathrm{~kg}$ for central Sweden and will be referred to as $0 \mathrm{~N}, 1 \mathrm{~N}, 2 \mathrm{~N}$ and $3 \mathrm{~N}$ in the text. The PK levels (P applied as mono superphosphate before 1994 and as triple superphosphate afterwards and $\mathrm{K}$ applied as potassium chloride) are $0 \mathrm{~kg}$; replacement of the harvested PK; replacement plus $15 \mathrm{~kg} \mathrm{P}$ and $40 \mathrm{~kg} \mathrm{~K}$; and replacement plus $30 \mathrm{~kg} \mathrm{P}$ and $80 \mathrm{~kg} \mathrm{~K}$ for the southern Swedish sites. For the central Swedish sites, levels were $0 \mathrm{~kg}$; replacement; replacement plus $20 \mathrm{~kg} \mathrm{P}$ and $50 \mathrm{~kg} \mathrm{~K}$; and replacement plus $30 \mathrm{~kg} \mathrm{P}$ and $80 \mathrm{~kg} \mathrm{~K}$. These respective levels are referred to as $0 \mathrm{PK}, 1 \mathrm{PK}, 2 \mathrm{PK}$ and $3 \mathrm{PK}$ in the text. In this study, we analysed the effect on SOC of the four PK levels with no $\mathrm{N}$ fertiliser (unfertilised control, $1 \mathrm{PK}_{0 \mathrm{~N}}, 2 \mathrm{PK}_{0 \mathrm{~N}}$, $3 \mathrm{PK}_{0 \mathrm{~N}}$ ) and the four $\mathrm{N}$ levels with no PK fertiliser (unfertilised control, $1 \mathrm{~N}_{0 \mathrm{PK}}, 2 \mathrm{~N}_{0 \mathrm{PK}}, 3 \mathrm{~N}_{\mathrm{OPK}}$ ) in the rotation without farmyard manure. As a positive reference, we also assessed the 1NPK, 2NPK and 3NPK treatments. A total of 88 pairs of unfertilised vs. fertilised soil was investigated, with $3 \mathrm{PK}_{0 \mathrm{~N}}$ only being present in 8 experiments, while all other treatments were present in all 10 experiments. The 4-year rotation investigated in the southern Swedish experiments consisted of barley, oilseed rape, winter wheat and sugar beet, while the 6-year rotation investigated in central Sweden consisted of barley, oats, oilseed rape, winter wheat, oats and winter wheat. Initial soil characteristics and climate data are presented in Table 2. A detailed description of the soil profile and mineralogical composition of the soil at the sites is provided in numerous publications (Carlgren and Mattsson, 
Table 1. The 10 experimental sites used in this study with coordinates $\left({ }^{\circ} \mathrm{N},{ }^{\circ} \mathrm{E}\right)$, starting year (in brackets: starting year in this study), year of last sampling, time span between first and last sampling (years) and length of the rotation (years).

\begin{tabular}{lllccc}
\hline Site & Coordinates & $\begin{array}{l}\text { Start of } \\
\text { experiment }\end{array}$ & $\begin{array}{c}\text { Last } \\
\text { sampling }\end{array}$ & $\begin{array}{c}\text { Time } \\
\text { span }\end{array}$ & $\begin{array}{c}\text { Rotation } \\
\text { length }\end{array}$ \\
\hline Fjärdingslov & $55.40,13.23$ & $1957(1962)$ & 2011 & 49 & 4 \\
Orup & $55.82,13.50$ & $1957(1962)$ & 2011 & 49 & 4 \\
Örja & $55.88,12.87$ & $1957(1962)$ & 2011 & 49 & 4 \\
S. Ugglarp & $55.63,13.43$ & $1957(1962)$ & 2007 & 45 & 4 \\
Ekebo & $55.98,12.87$ & $1957(1962)$ & 2011 & 49 & 4 \\
Vreta Kloster & $58.50,15.50$ & 1966 & 2007 & 45 & 6 \\
Högåsa & $58.50,15.45$ & 1966 & 2007 & 45 & 6 \\
Bjertorp & $58.23,13.13$ & 1966 & 2007 & 45 & 6 \\
Kungsängen & $59.83,17.67$ & 1963 & 2011 & 49 & 6 \\
Fors & $60.33,17.48$ & 1963 & 2011 & 49 & 6 \\
\hline
\end{tabular}

Table 2. Basic soil parameters and climate data for the 10 study sites at the beginning of the experiments: clay and sand content (\%), soil organic carbon content $(\%)$, soil $\mathrm{pH}$, bulk density $\left(\mathrm{g} \mathrm{cm}^{-3}\right)$, mean annual temperature (MAT) $\left({ }^{\circ} \mathrm{C}\right)$ and mean annual precipitation (MAP) (mm).

\begin{tabular}{lrrrrrrr}
\hline Site & Clay & Sand & SOC & pH & $\begin{array}{c}\text { Bulk } \\
\text { density }\end{array}$ & MAT & MAP \\
\hline Fjärdingslov & 14 & 62 & 1.4 & 7.9 & 1.66 & 7.7 & 550 \\
Orup & 12 & 59 & 2.4 & 6.6 & 1.51 & 8.3 & 769 \\
Örja & 23 & 52 & 1.1 & 7.8 & 1.72 & 8.3 & 593 \\
S. Ugglarp & 12 & 63 & 1.5 & 6.7 & 1.50 & 7.7 & 686 \\
Ekebo & 18 & 47 & 3.1 & 6.9 & 1.44 & 8.2 & 622 \\
Vreta Kloster & 48 & 8 & 2.1 & 6.2 & 1.43 & 6.4 & 527 \\
Högåsa & 7 & 78 & 2.4 & 6.7 & 1.38 & 6.4 & 527 \\
Bjertorp & 30 & 16 & 2.2 & 6 & 1.37 & 6.5 & 593 \\
Kungsängen & 56 & 4 & 2.1 & 7.1 & 1.31 & 6 & 543 \\
Fors & 18 & 24 & 2.2 & 7.7 & 1.49 & 5.5 & 613 \\
\hline
\end{tabular}

2001). A summary is provided in Table 2. The soils are sampled regularly to a depth of $20 \mathrm{~cm}$ (plough layer), air-dried and sieved to $2 \mathrm{~mm}$. Initial plot-wise carbon data were available for all experiments. Samples with $\mathrm{pH}\left(\mathrm{H}_{2} \mathrm{O}\right)$ exceeding 6.7 were treated with $2 \mathrm{M} \mathrm{HCl}$ to remove carbonates. Total carbon and nitrogen was determined by dry combustion using an elemental analyser (LECO-CNS-200, St. Joseph, MI, USA). $\mathrm{P}$ and $\mathrm{K}$ were both extracted using two different methods, according to Swedish standards: $0.1 \mathrm{M} \mathrm{NH}_{4}$ lactate and $0.4 \mathrm{M}$ HOAc adjusted to $\mathrm{pH} 3.75$ and subsequently analysed using an inductively coupled plasma apparatus (ICPAES Optima 5300, Waltham, MA, USA). The initial carbon values were measured either with loss on ignition or the Walkley-Black wet oxidation, although there is no good technical documentation on that issue. However, due to the fact that we were investigating differences between treatments, a possible bias induced by methodological considerations should be insignificant or very small.

\subsection{Calculation of carbon stocks and dynamics}

The SOC stocks were calculated by multiplying soil bulk density, sampling depth and SOC concentration. To account for the fact that equal soil masses should be compared within one experiment (Ellert and Bettany, 1995), we used the initial average bulk density value for all treatments, which mathematically equals a depth adjustment to obtain the same soil mass from individual bulk density values (Poeplau et al., 2011). Bulk density values are reported for all experiments (Table 1) and did not change significantly over time (data not shown). The difference in SOC stocks between the unfertilised control and the respective treatment was then determined. The $\mathrm{N}$ and $\mathrm{PK}$ treatment effects on SOC stocks ( $\left.\triangle \mathrm{SOC}_{\text {treatment }}\right)$ was calculated treatment-wise from the difference between initial $\left(\Delta \mathrm{SOC}_{\text {initial }}\right)$ and final $\left(\Delta \mathrm{SOC}_{\text {final }}\right)$ SOC stock in treatment and control plots:

$\Delta \mathrm{SOC}_{\text {treatment }}=\Delta \mathrm{SOC}_{\text {final }}-\Delta \mathrm{SOC}_{\text {initial }}$.

The southern Swedish experiments were initiated in 1957 , but the experiment was first divided into subplots as they exist today in 1962, which was the first year in which plot-wise soil sampling was conducted. Thus, for these five sites, 1962 was the reference year used to calculate $\Delta \mathrm{SOC}_{\text {treatment }}$. The difference in the annual net flux of carbon $\left(\Delta\right.$ Cflux $\left._{n e t}\right)$ was calculated by dividing $\triangle \mathrm{SOC}_{\text {treatment }}$ by the number of years between the first and the latest sampling. This represents the mean annual SOC stock change rate in a certain treatment compared with the unfertilised control. As a proxy for carbon inputs (Bolinder et al., 2007), we calculated relative differences in annual yields between any considered fertiliser treatment and the unfertilised control and averaged those differences over the whole period.

\subsection{Statistics}

Linear mixed effect models were used to assess whether any of the fertiliser treatments had a significant effect on yields and SOC stock changes across sites. Treatment was used as the fixed effect, while site was used as a random effect. We calculated the model twice for both fertiliser regimes $(\mathrm{N}$ and PK-fertilised soils), either using all levels as individual treatments or using levels 1-3 together as one treatment (fertilised) testing it against the unfertilised control. Multiple linear regression models were used to explain the observed variability in the response to PK fertilisation with different explanatory variables for all three PK levels and all $\mathrm{N}$ levels separately. These were clay content, sand content, average initial $\mathrm{C}, \mathrm{N}, \mathrm{P}_{\text {available }}, \mathrm{K}_{\text {available contents, stoichio- }}$ metric ratios of those elements, average initial soil $\mathrm{pH}$, average losses of available phosphorus and potassium in the unfertilised control between the first and last sampling; final differences in available phosphorus and potassium between the unfertilised control and the fertilised treatment; and final differences in soil $\mathrm{pH}$ between the control and the fertilised 
treatment and relative yield increase after fertilisation. Due to the high number of potential explanatory variables, multimodel inference ( $\mathrm{R}$ package MuMIn) was used for a priori model selection and model averaging based on the Akaike information criterion (AIC). Error ranges shown in the text and in diagrams are standard deviations. All statistics were performed using the R software.

\section{Results}

As expected, we observed an average increase in yields of $1 \%\left(1 \mathrm{PK}_{0 \mathrm{~N}}\right), 10 \%\left(2 \mathrm{PK}_{0 \mathrm{~N}}\right)$ and $15 \%\left(3 \mathrm{PK}_{0 \mathrm{~N}}\right)($ Fig. 1a) following $\mathrm{PK}$ fertilisation. This increase was significant for $2 \mathrm{PK}_{0 \mathrm{~N}}(p=0.012), 3 \mathrm{PK}_{0 \mathrm{~N}}(p=0.007)$ and for all pairs together $(p=0.002)$. An equal, yet more pronounced response of NPP to fertilisation was observed for the different $\mathrm{N} \mathrm{lev-}$ els (30 pairs) with significant increases of 45,80 and $86 \%$ for $1 \mathrm{~N}_{0 \mathrm{PK}}, 2 \mathrm{~N}_{0 \mathrm{PK}}$ and $3 \mathrm{~N}_{0 \mathrm{PK}}$ respectively.

Despite these expected positive effects on yields under both fertiliser regimes, we found contrasting responses of SOC stocks. In the PK-fertilised soils, we detected a relative SOC stock depletion over time for 22 pairs out of 28 pairs (Fig. 1b), which was statistically significant ( $p=0.004)$. All experiments have been running for more than 40 years and since we accounted for the initial differences in SOC between experimental plots, we considered that any influence of prior land use would be negligible. Only at one site, Fors, was no decrease in SOC at all observed as a consequence of PK fertilisation. On average, the negative effect of PK fertilisation increased with $\mathrm{PK}$ level: with $1 \mathrm{PK}_{0 \mathrm{~N}}$, SOC stocks decreased by $2.0 \pm 4.3 \mathrm{Mg} \mathrm{ha}^{-1}$ or $0.04 \pm 0.09 \mathrm{Mg} \mathrm{ha}^{-1} \mathrm{yr}^{-1}$ (ns); with $2 \mathrm{PK}_{0 \mathrm{~N}}$, they decreased by $2.3 \pm 5.8 \mathrm{Mg} \mathrm{ha}^{-1}$ or $0.05 \pm 0.12 \mathrm{Mg} \mathrm{ha}^{-1} \mathrm{yr}^{-1}$ (ns); and with $3 \mathrm{PK}_{0 \mathrm{~N}}$, they significantly $(p=0.008)$ decreased by $4.2 \pm 3.3 \mathrm{Mgha}^{-1}$ or $0.09 \pm 0.07 \mathrm{Mg} \mathrm{ha}^{-1} \mathrm{yr}^{-}$(Fig. 2). SOC stocks under PK fertilisation alone thus developed directly disproportionately to yields, which is in contrast to the observations in the $\mathrm{N}$ fertilised soils (Fig. 2). Although SOC stock changes were not significant after long-term $\mathrm{N}$ fertilisation and even $1 \mathrm{~N}_{0 \mathrm{PK}}$ did lead to slight losses of SOC, the trend of increasing yields with increasing $\mathrm{N}$ level was tracked by the trend in SOC stocks (Fig. 2).

The effect of NPK fertilisation on NPP was synergistic and was thus higher than the sum of the increases after PK and $\mathrm{N}$ fertilisation alone (Fig. 1a). This strong increase in $\mathrm{C}$ input also positively affected SOC stocks.

Observed annual SOC stock changes at different $\mathrm{PK}_{0 \mathrm{~N}}$ levels were partly explained by the variables considered, although the degree of explanation varied across PK levels. The changes in the $1 \mathrm{PK}_{0 \mathrm{~N}}$ treatments were best explained by mean annual temperature (MAT), average initial SOC concentration and average initial $\mathrm{C}: \mathrm{P}_{\text {available }}$ ratio, whereby all three variables were negatively correlated with annual SOC stock changes. The variables used explained $92 \%$ of the ob-

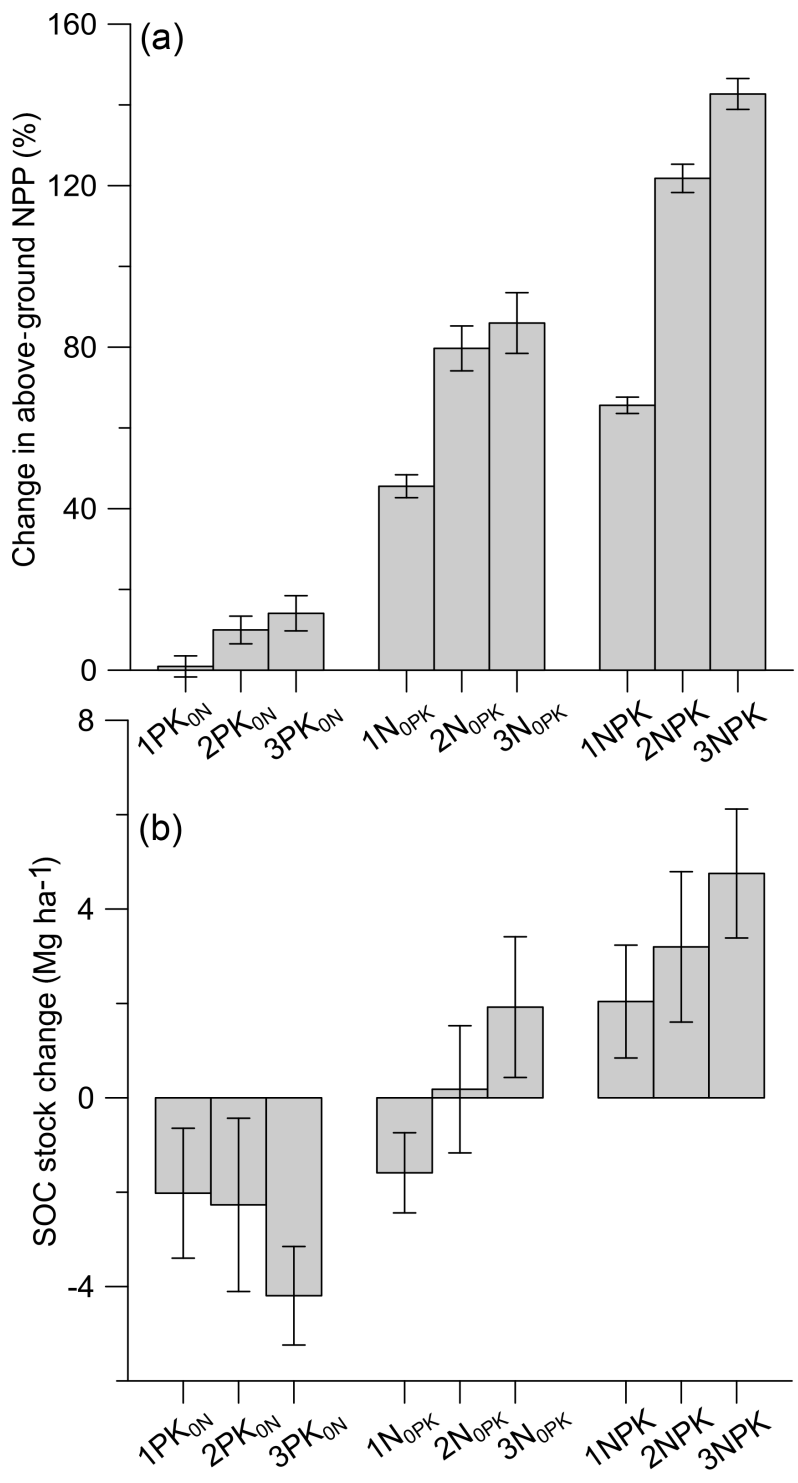

Figure 1. Average relative yield differences (a) and average soil organic carbon (SOC) stock differences (b) between fertilised and unfertilised soils for all investigated levels of fertilisation $\left(\mathrm{PK}_{0 \mathrm{~N}}\right.$, $\mathrm{N}_{0 \mathrm{PK}}, \mathrm{NPK}$ ) with standard errors.

served variation $\left(R^{2}=0.92\right)$ (Fig. 3). Losses of SOC were thus most pronounced at sites with high SOC concentration, a relatively warm climate and low available $\mathrm{P}$. The effect of $2 \mathrm{PK}_{0 \mathrm{~N}}$ fertilisation on annual SOC stock changes was only significantly correlated with average initial soil $\mathrm{pH}$ (Fig. 3) $\left(R^{2}=0.23\right)$, while that of $0 \mathrm{~N} 3 \mathrm{PK}$ was significantly correlated with mean annual precipitation (MAP) and initial soil carbon, achieving $70 \%$ explanation.

In contrast to the $\mathrm{PK}_{0 \mathrm{~N}}$ fertiliser levels, we found significant explanatory power of relative yield increases in SOC stock change in the $1 \mathrm{~N}_{0 \mathrm{PK}}$ levels, which indicates the link between carbon input and carbon stock dynamic. Furthermore, $1 \mathrm{~N}_{\text {OPK }}$ was negatively influenced by the $\mathrm{C}: \mathrm{P}_{\text {available }}$ ratio in 


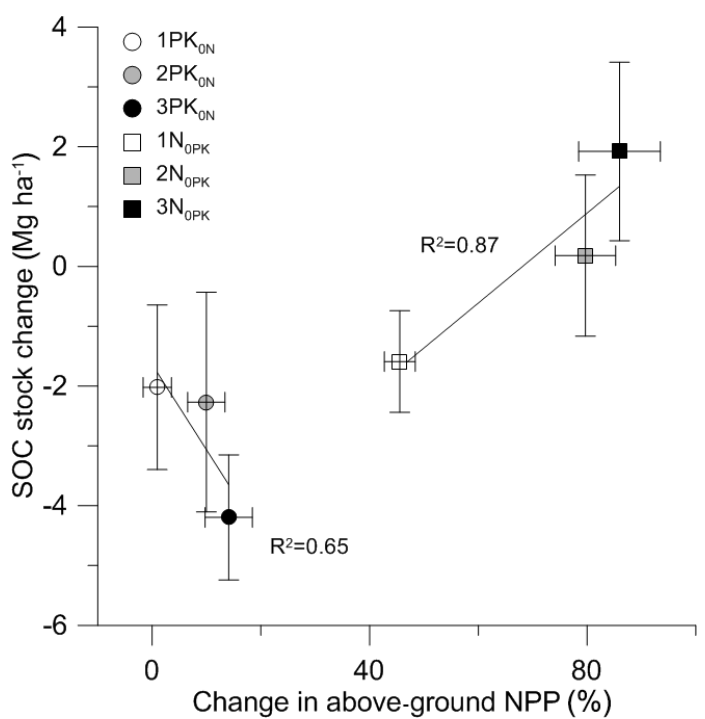

Figure 2. Correlation of average SOC stock differences between fertilised and unfertilised soils and average yield differences in fertilised and unfertilised soils with separate regression lines for the Pand $\mathrm{N}$-fertilised regimes. Error bars indicate standard errors.

the soil, with more negative changes in P-poor soils adding up to a total explanation of $39 \%$ of the observed variance. The $C: P_{\text {available }}$ ratio was also the only variable which significantly explained some of the variability in observed SOC responses to $2 \mathrm{~N}_{0 \mathrm{PK}}\left(R^{2}=0.34\right.$, Fig. 3$)$.

\section{Discussion}

In most agricultural long-term experiments assessing the effects of mineral fertilisers on SOC, the focus is on the application rates or sources of nitrogen (Lugato et al., 2006; Malhi et al., 1997) because they may be more directly related to applied agronomy issues. The majority of existing studies did observe increased yields and SOC stocks with increased $\mathrm{N}$ or NPK fertilisation, leading to the perception that carbon input is the major driver for SOC dynamics in agricultural systems (Christopher and Lal, 2007). This pattern has been similarly observed in our study. Our finding that phosphorus and potassium (PK) fertilisation can have a negative net effect on SOC stocks in the absence of nitrogen, significantly so at the highest rate of PK fertilisation, has not been highlighted before. However, in several studies, P fertilisation was one among many other investigated fertiliser treatments without receiving much attention in the respective discussion. In those long-term experiments, mixed responses of P or PK fertilisation on SOC stocks have been observed. Some studies showed losses of SOC (Wyngaard et al., 2012; Yan et al., 2013; Zhu et al., 2007), while others found gains (Shao and Zheng, 2014; Zhengchao et al., 2013). The effect of $\mathrm{P}$ or PK fertilisation on yields was mostly slightly positive, which is in line with our findings for the Swedish sites.

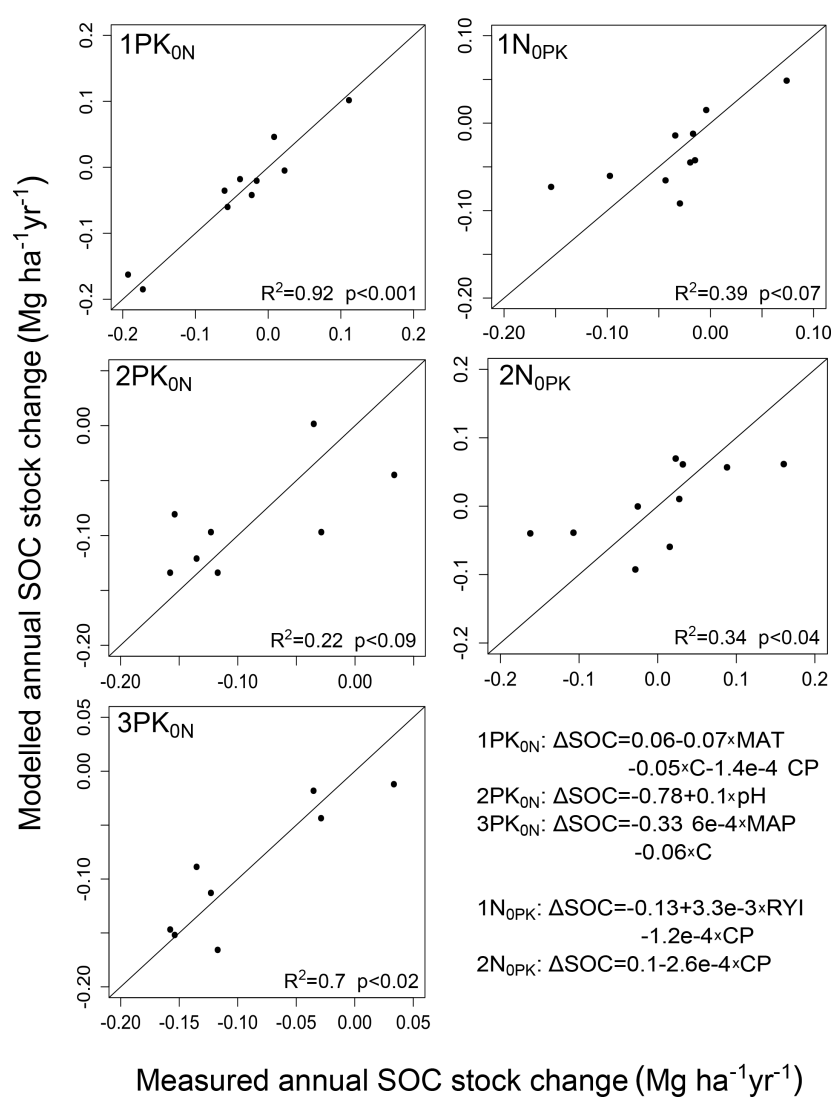

Figure 3. Comparison of measured and modelled annual soil organic carbon (SOC) stock change $\left(\mathrm{Mgha}^{-1} \mathrm{yr}^{-1}\right)$ for all phosphorus-potassium (PK) levels and two $\mathrm{N}$ levels, with model equations in which MAT is mean annual temperature $\left({ }^{\circ} \mathrm{C}\right)$, MAP mean annual precipitation $(\mathrm{mm}), \mathrm{pH}$ average initial soil $\mathrm{pH}, \mathrm{C}$ average initial SOC concentration (\%), CP the average initial $\mathrm{C}: \mathrm{P}_{\text {available }}$ ratio and $\mathrm{RYI}$ the relative yield increase $(\%)$.

It is, however, a new observation that SOC stock changes do not always seem to follow changes in NPP and annual C inputs to soil, as the major source of SOC. This requires explanation. We considered four different mechanisms, each of which could explain parts of this observed depletion in SOC stocks under presumed increased carbon inputs.

1. Fertilisation with $P$ stimulates heterotrophic respiration. A strong microbial response to $\mathrm{P}$ addition has been observed in several studies, mostly conducted in Plimited tropical forests (Cleveland and Townsend, 2006; Nottingham et al., 2015) but also in northern hardwood forests (Fisk et al. 2015). Craine et al. (2007) tested the effect of $\mathrm{N}$ and $\mathrm{P}$ addition on mineralisation for a wide range of different plant materials in different soils and found that $\mathrm{C}$ mineralisation decreased with $\mathrm{N}$ availability, while $\mathrm{P}$ fertilisation increased short- and long-term $\mathrm{C}$ mineralisation. They concluded that basic stoichiometric decomposition theory needs to be revised and carbon cycling models restructured to take into account 
the effect of $\mathrm{P}$ on SOC turnover. It is not entirely understood why $\mathrm{N}$ and $\mathrm{P}$ additions show opposing effects on microbial activity, but shifts in microbial community structure could play an important role (Ramirez et al., 2012). Recently, Hartman and Richardson (2013) found that the metabolic quotient of microbes (i.e., respiration per biomass) increased significantly following the addition of inorganic $\mathrm{P}$, which could indicate that microbial activity in soil is largely controlled by $\mathrm{P}$ availability. In addition to microbial metabolism, the availability of $\mathrm{P}$ an $\mathrm{N}$ has also been shown to trigger the resource allocation to exoenzymes that break down organic matter (Sinsabaugh and Moorhead, 1994). Extractable phosphorus has been a stronger predictor of $\mathrm{C}$ mineralisation than land use (Strickland et al., 2010). Cleveland and Townsend (2006) reported an in situ increase in $\mathrm{CO}_{2}$ efflux of $37 \%$ after P fertilisation and an in vitro $12 \%$ higher respiration in the P-fertilised than in the unfertilised soil after adding glucose. Fisk et al. (2015) reported $28-122 \%$ higher $\mathrm{CO}_{2}$ efflux in the P-fertilised soil than in the unfertilised soil, depending on added labile C substrates. Considering these observations, it is not an unrealistic hypothesis that an increase in respiration could be the most important mechanism underlying the observed changes in SOC stocks. Furthermore, the average relative phosphorus demand of microbial biomass corresponds to a $\mathrm{C}: \mathrm{P}$ ratio of $60: 1$, and a global average $\mathrm{C}: \mathrm{P}$ ratio of $186: 1$ in soils is globally well constrained (Cleveland and Liptzin, 2007). In our study, the average $C: P_{\text {available }}$ ratio in the unfertilised control soils was $706: 1$. Thus, the stimulating effect of $\mathrm{P}$ on microbial activity may override the stimulating effect on plant growth, leading to net losses of SOC.

2. Colonisation of roots with arbuscular mycorrhizal fungi $(A M F)$ is reduced when easily available $P$ is applied to soil (Grant et al., 2005; Nagahashi et al., 1996). The main role of AMF hyphae is to increase root uptake capacity for nutrients, including $\mathrm{P}$, by enlarging the surface area of the root system (Pearson and Jakobsen, 1993). In return, the fungi receive carbon assimilates from the plant in the form of carbohydrates. It has been shown that plants can provide up to $17 \%$ of their photosynthetic carbon to the fungi (AMF, among other mycorrhiza types) (Hobbie and Hobbie, 2006). Clemmensen et al. (2013) identified root-associated fungi as important regulators of ecosystem carbon dynamics. In addition to the higher $\mathrm{C}$ input to soil through greater $\mathrm{AMF}$ colonisation, AMF-derived carbon (glomalin) may lead to the formation of more stable aggregates, protecting organic matter (Miller and Jastrow, 2000) and thereby preserving the SOC pool (Grant et al., 2005; Nagahashi et al., 1996; Rillig et al., 2001). Therefore, a decrease in AMF colonisation as a consequence of PK fertilisation can potentially have negative effects on SOC stocks.
3. Fertilisation with $P$ decreases plant root: shoot ratio. A deficiency in major nutrients ( $\mathrm{N}, \mathrm{P}$ and $\mathrm{K}$ ) generally leads to an increased root: shoot ratio (Wilson, 1988). Under $\mathrm{N}$ deficiency, a typical increase in root : shoot ratio is in the range of 15 to $50 \%$ (Hansson et al., 1987; Welbank et al., 1973). There is also evidence that $P$ fertilisation can decrease the root: shoot ratio of crop plants (Ericsson, 1995; Marschner et al., 1996) compared with unfertilised soil. This change in root: shoot ratio occurs because nutrient deficiency forces crops to develop larger root systems than under conditions of sufficient nutrient supply (Marschner et al., 1996). Moreover, root-derived carbon has been found to contribute more to the stable soil carbon pool than shootderived carbon (Kätterer et al., 2011). Carbon inputs to the soil are usually yield-based estimates assuming stable carbon allocation coefficients to different plant parts across fertiliser regimes. This is common practice in soil carbon modelling, although there are indications that it may be erroneous. The observed increase in yield for the $0 \mathrm{~N}$ PK treatments which was 1, 10 and $15 \%$ for $1 \mathrm{PK}_{0 \mathrm{~N}}, 2 \mathrm{PK}_{0 \mathrm{~N}}$ and $3 \mathrm{PK}_{0 \mathrm{~N}}$ respectively leads to increased $\mathrm{C}$ input to the soil when assuming stable ratios of plant carbon allocation. However, relative to the unfertilised control, if a certain shift in root : shoot ratio did occur, PK fertilisation could actually have caused a decrease in total NPP. Thus, despite higher above-ground NPP, the smaller root inputs and the associated qualitative shift of the total carbon input may have contributed significantly to the observed SOC losses after $\mathrm{PK}_{0 \mathrm{~N}}$ fertilisation. However, it seems unrealistic to expect the disproportional trend of yields and SOC stocks to be explained by the root: shoot ratio shift. Unchanged SOC stocks over all $\mathrm{PK}_{0 \mathrm{~N}}$ levels could be expected but most likely not decreases.

4. Stronger $N$ mining leads to higher mineralisation of $C$. In the $0 \mathrm{~N}$ PK-fertilised plots with higher yields, more $\mathrm{N}$ is lost from the system through export by harvest. Such a negative effect of PK fertilisation on soil $\mathrm{N}$ has been observed by Glendining et al. (1997). This could have increased the $\mathrm{N}$ deficiency in the soil, leading to stronger $\mathrm{N}$ mining by microbes, a process in which nutrients are mobilised via decomposition of more stable organic matter (Fontaine et al., 2004). This may lead to loss of $\mathrm{C}$ from this pool and is in line with the findings of Kirkby et al. (2011) and (2013), who found that SOC sequestration relies on the availability of nutrients and that the stoichiometric ratio of $\mathrm{C}: \mathrm{N}: \mathrm{P}: \mathrm{S}$ of stable soil organic matter is globally well constrained. We did not find any negative effect of PK fertilisation on SOC stocks in the presence of nitrogen fertilisation. This is in support of the hypothesis that the decreasing SOC stocks we observed were instead induced by an indirect response to PK fertilisation. However, the estimated sur- 
plus of $\mathrm{N}$ extraction in the fertilised plots (with an average crop $\mathrm{C}: \mathrm{N}$ ratio of 70 ) accounted for only $2-20 \%$ of the total soil $\mathrm{N}$ loss (average soil $\mathrm{C}: \mathrm{N}$ ratio of 11) after ON PK fertilisation. Consequently, this mechanism was probably only of minor importance in this study. Furthermore, Cleveland and Townsend (2006) found higher respiration when adding glucose with $\mathrm{N}+\mathrm{P}$ as compared to the addition of glucose and $\mathrm{N}$. This does indicate that the stimulating effect of $\mathrm{P}$ on heterotrophic respiration is not restricted to $\mathrm{N}$-deficient soils.

The relative importance of each of the first three mechanisms for SOC dynamics in the PK-fertilised but N-deficient regime remains speculative, since $\mathrm{CO}_{2}$ efflux, abundance of AMF and belowground biomass production were not measured. However, the observed explanatory power of available $\mathrm{C}$, available $\mathrm{P}$, soil $\mathrm{pH}$ and the climate parameters MAT and MAP provide support for mechanisms (1) and (2), i.e. increased soil respiration and less AMF colonisation due to 0N PK fertilisation. Temperature, moisture, substrate availability and nutrient availability are key drivers for microbial activity. Surprisingly, SOC dynamics of the $\mathrm{PK}_{0 \mathrm{~N}}$-fertilised treatments were independent of relative yield increase and thus carbon input, while the variability in SOC dynamics in $1 \mathrm{~N}_{\mathrm{OPK}}$ was partly explained by differences in relative yield increase. This fits the observation that carbon dynamic in the $\mathrm{PK}_{0 \mathrm{~N}}$ treatments was decoupled from above-ground NPP, while it was positively correlated with above-ground NPP in the $\mathrm{N}_{\mathrm{OPK}}$ treatments. Furthermore, Clark et al. (1999) found twice the amount of AMF biomass in a soil with $\mathrm{pH} 4 \mathrm{com}-$ pared with a soil of $\mathrm{pH} \mathrm{5,} \mathrm{which} \mathrm{is} \mathrm{in} \mathrm{line} \mathrm{with} \mathrm{the} \mathrm{more} \mathrm{pro-}$ nounced SOC losses we observed in low-pH soils. Attributing the losses completely to changes in heterotrophic respiration, as developed above, appeared realistic when compared with the strong stimulations observed in other studies. However, the tendency of SOC losses after 1N OPK fertilisation may support the hypothesis of a significantly altered root: shoot ratio, which has also been observed for $\mathrm{N}$ and $\mathrm{P}$ deficiencies (Wilson, 1988). However, these losses could also be explicable by $\mathrm{P}$ mining due to a higher extraction of $\mathrm{P}$ in the N-fertilised soils.

Craine et al. (2007) provided evidence for the $\mathrm{N}$ mining theory but did not find any indications for $\mathrm{P}$ mining. This could potentially be related to the fact that soil $\mathrm{N}$ is mainly stored in organic matter, while considerable fractions of soil $\mathrm{P}$ are also stored in inorganic forms; thus, $\mathrm{P}$ mining would be less related to the breakdown of organic matter. However, the fact that $\mathrm{P}$ availability did significantly trigger SOC responses to $\mathrm{N}$ fertilisation (Fig. 3; higher $\mathrm{C}: \mathrm{P}_{\text {available }}$ ratio led to less increase or more decrease in SOC) could mean that $\mathrm{P}$ mining did to some extent play a role in the studied experiments. The positive effect of N on NPP was much more pronounced than the effect of PK, which was most likely enough to overshadow any nutrient control on SOC decomposition. It is thus not possible to show the differences between the two fertiliser regimes in carbon output or any of the abovementioned mechanisms in the present data set. It can, however, be concluded that SOC dynamics were input-driven under $\mathrm{N}$ fertilisation with $\mathrm{P}$ deficiency but output-driven under $\mathrm{PK}$ fertilisation with $\mathrm{N}$ deficiency.

In this study, we were unable to separate the effect of $P$ from a potential effect of $\mathrm{K}$, since the two elements were applied in combination. Previously, Shao and Zheng (2014) found a slightly positive effect of $\mathrm{K}$ fertilisation on SOC stocks, whereas Yan et al. (2013) found no changes in yield and SOC stock compared with the unfertilised soil. Several studies have shown that $\mathrm{K}$ has an opposing but less pronounced effect the on root: shoot ratio than $\mathrm{P}$ (Ericsson, 1995; Hackett, 1968). Van Cleve and Moore (1978) found strongly increasing soil respiration with $\mathrm{N}$ and $\mathrm{P}$ fertilisation but slightly decreasing soil respiration with $\mathrm{K}$ fertilisation. These studies indicate that the negative effect of $\mathrm{PK}_{0 \mathrm{~N}}$ fertilisation we observed in the Swedish experiments is most likely related to $\mathrm{P}$ fertilisation, while $\mathrm{K}$ could even have counterbalanced this effect to a certain degree. A pH effect on SOC decomposition due to different fertiliser regimes (especially due to $\mathrm{K}$ fertilisation) could be excluded, since no systematic difference in $\mathrm{pH}$ was observed across treatments. This may be due to the fact that the soils were repeatedly limed, according to local agricultural practices. We cannot anticipate any other mechanism following $\mathrm{K}$ fertilisation in our study that could have led to SOC losses. However, it is recognised that the combined fertilisation of $\mathrm{P}$ and $\mathrm{K}$ used in this study does not allow a clear separation of the individual effects of these two elements. In the few available studies in which $\mathrm{P}$ effects were studied specifically, $\mathrm{P}$ was also applied in combination with $\mathrm{K}$ as $\mathrm{KH}_{2} \mathrm{PO}_{4}$ (Cleveland and Townsend, 2006; Craine et al., 2007).

\section{Conclusions}

For soils receiving no $\mathrm{N}$ fertiliser, a negative effect of phosphorus and potassium (PK) fertilisation on SOC stocks was observed in 9 out of the 10 meta-replicated Swedish longterm experiments studied. To our knowledge, it is the first study that shows a significant depletion of SOC stocks after PK fertilisation in the absence of $\mathrm{N}$ fertilisation. The processes involved may be diverse and are certainly not well studied, in contrast to the rising awareness of the importance of soil nutrients for net ecosystem carbon fluxes (Reed et al., 2011). According to the literature, of these two elements, $P$ rather than $\mathrm{K}$ is likely to have the highest impact on ecosystem carbon fluxes. This finding requires attention, since a positive effect of N on NPP and SOC stock changes is widely accepted. It may be helpful to predict SOC stock changes after sudden stoichiometric imbalances in ecosystems as induced by fires, atmospheric deposition or enhanced soil $\mathrm{P}$ extraction by legumes. Many studies focus on certain aspects of SOC cycling, such as soil respiration or the contribution 
of AMF to the total SOC pool. The results obtained from these studies are obviously helpful, e.g. to certain management practices, in identifying potential processes involved in soil responses. However, as long as the relative contribution of each process remains unknown, it is difficult to refine our holistic knowledge of SOC dynamics. The observed negative effect of $\mathrm{PK}_{0 \mathrm{~N}}$ fertilisation, with its diverse potential causes, calls for a more integrated approach for studying SOC dynamics.

Acknowledgements. We gratefully acknowledge the Faculty of Natural Resources and Agricultural Sciences for providing funds for maintenance of the long-term field experiments. Financial support for this study was partly provided by that Faculty and partly by the Swedish Farmers' Foundation for Agricultural Research (grant no. H1233013).

Edited by: Y. Kuzyakov

\section{References}

Allen, A. S. and Schlesinger, W. H.: Nutrient limitations to soil microbial biomass and activity in loblolly pine forests, Soil Biol. Biochem., 36, 581-589, 2004.

Alvarez, R.: A review of nitrogen fertilizer and conservation tillage effects on soil organic carbon storage, Soil Use Manage., 21, 3852, 2005.

Bolinder, M., Janzen, H., Gregorich, E., Angers, D., and VandenBygaart, A.: An approach for estimating net primary productivity and annual carbon inputs to soil for common agricultural crops in Canada, Agr. Ecosyst. Environ., 118, 29-42, 2007.

Bradford, M. A., Fierer, N., and Reynolds, J. F.: Soil carbon stocks in experimental mesocosms are dependent on the rate of labile carbon, nitrogen and phosphorus inputs to soils, Funct. Ecol., 22, 964-974, 2008.

Carlgren, K. and Mattsson, L.: Swedish Soil Fertility Experiments, Acta Agr. Scand. B-S. P., 51, 49-76, 2001.

Christopher, S. F. and Lal, R.: Nitrogen Management Affects Carbon Sequestration in North American Cropland Soils, Cr. Rev. Plant Sci., 26, 45-64, 2007.

Clark, R. B., Zeto, S. K., and Zobel, R. W.: Arbuscular mycorrhizal fungal isolate effectiveness on growth and root colonization of Panicum virgatum in acidic soil, Soil Biol. Biochem., 31, 17571763, 1999.

Clemmensen, K. E., Bahr, A., Ovaskainen, O., Dahlberg, A., Ekblad, A., Wallander, H., Stenlid, J., Finlay, R. D., Wardle, D. A., and Lindahl, B. D.: Roots and Associated Fungi Drive Long-Term Carbon Sequestration in Boreal Forest, Science, 339, 1615-1618, 2013.

Cleveland, C. C. and Liptzin, D.: C: N: P stoichiometry in soil: is there a "Redfield ratio" for the microbial biomass?, Biogeochemistry, 85, 235-252, 2007.

Cleveland, C. C. and Townsend, A. R.: Nutrient additions to a tropical rain forest drive substantial soil carbon dioxide losses to the atmosphere, P. Natl. Acad. Sci., 103, 10316-10321, 2006.

Cleveland, C. C., Townsend, A. R., and Schmidt, S. K.: Phosphorus limitation of microbial processes in moist tropical forests: Evi- dence from short-term laboratory incubations and field studies, Ecosystems, 5, 680-691, 2002.

Craine, J. M., Morrow, C., and Fierer, N.: Microbial nitrogen limitation increases decomposition, Ecology, 88, 2105-2113, 2007.

Ellert, B. H. and Bettany, J. R.: Calculation of organic matter and nutrients stored in soils under contrasting management regimes, Can. J. Soil Sci., 75, 529-538, 1995.

Ericsson, T.: Growth and shoot: root ratio of seedlings in relation to nutrient availability, Plant Soil, 167-168, 205-214, 1995.

Fisk, M., Santangelo, S., and Minick, K.: Carbon mineralization is promoted by phosphorus and reduced by nitrogen addition in the organic horizon of northern hardwood forests, Soil Biol. Biochem., 81, 212-218, 2015.

Fontaine, S., Bardoux, G., Abbadie, L., and Mariotti, A.: Carbon input to soil may decrease soil carbon content, Ecol. Lett., 7, 314320, 2004.

Glendining, M. J., Poulton, P. R., Powlson, D. S., and Jenkinson, D. S.: Fate of ${ }^{15} \mathrm{~N}$-labelled fertilizer applied to spring barley grown on soils of contrasting nutrient status, Plant Soil, 195, 83-98, 1997.

Grant, C., Bittman, S., Montreal, M., Plenchette, C., and Morel, C.: Soil and fertilizer phosphorus: Effects on plant $\mathrm{P}$ supply and mycorrhizal development, Can. J. Plant Sci., 85, 3-14, 2005.

Hackett, C.: A study of the root system of barley, New Phyt., 67, 287-299, 1968.

Hansson, A.-C., Pettersson, R., and Paustian, K.: Shoot and root production and nitrogen uptake in Barley, with and without nitrogen fertilization, J. Agron. Crop Sci., 158, 163-171, 1987.

Hartman, W. H. and Richardson, C. J.: Differential nutrient limitation of soil microbial biomass and metabolic quotients $\left(q \mathrm{CO}_{2}\right)$ : is there a biological stoichiometry of soil microbes?, PloS One, 8, e57127, doi:10.1371/journal.pone.0057127, 2013.

Hobbie, J. E. and Hobbie, E. A.: ${ }^{15} \mathrm{~N}$ in symbiotic fungi and plants estimates nitrogen and carbon flux rates in arctic tundra, Ecology, 87, 816-822, 2006.

Kätterer, T., Bolinder, M. A., Andrén, O., Kirchmann, H., and Menichetti, L.: Roots contribute more to refractory soil organic matter than above-ground crop residues, as revealed by a longterm field experiment, Agr. Ecosyst. Environ., 141, 184-192, 2011.

Kätterer, T., Bolinder, M., Berglund, K., and Kirchmann, H.: Strategies for carbon sequestration in agricultural soils in northern $\mathrm{Eu}-$ rope, Acta Agr. Scand. A-An., 62, 181-198, 2012.

Kirkby, C. A., Kirkegaard, J. A., Richardson, A. E., Wade, L. J., Blanchard, C., and Batten, G.: Stable soil organic matter: A comparison of C:N:P:S ratios in Australian and other world soils, Geoderma, 163, 197-208, 2011.

Kirkby, C. A., Richardson, A. E., Wade, L. J., Batten, G. D., Blanchard, C., and Kirkegaard, J. A.: Carbon-nutrient stoichiometry to increase soil carbon sequestration, Soil Biol. Biochem., 60, 77-86, 2013.

Ladha, J. K., Reddy, C. K., Padre, A. T., and van Kessel, C.: Role of nitrogen fertilization in sustaining organic matter in cultivated soils, J. Environ. Qual., 40, 1756-1766, 2011.

Lal, R.: Global potential of soil carbon sequestration to mitigate the greenhouse effect, Cr. Rev. Plant Sci., 22, 151-184, 2003.

Lu, M., Zhou, X., Luo, Y., Yang, Y., Fang, C., Chen, J., and Li, B.: Minor stimulation of soil carbon storage by nitrogen addition: a meta-analysis, Agr. Ecosyst. Environ., 140, 234-244, 2011. 
Lugato, E., Berti, A., and Giardini, L.: Soil organic carbon (SOC) dynamics with and without residue incorporation in relation to different nitrogen fertilisation rates, Geoderma, 135, 315-321, 2006.

Malhi, S. S., Nyborg, M., Harapiak, J. T., Heier, K., and Flore, N. A.: Increasing organic $\mathrm{C}$ and $\mathrm{N}$ in soil under bromegrass with long-term N fertilization, Nutr. Cycl. Agroecosys., 49, 255-260, 1997.

Marschner, H., Kirkby, E. A., and Cakmak, I.: Effect of mineral nutritional status on shoot-root partitioning of photoassimilates and cycling of mineral nutrients, J. Exp. Bot., 47, 1255-1263, 1996.

Milcu, A., Heim, A., Ellis, R., Scheu, S., and Manning, P.: Identification of General Patterns of Nutrient and Labile Carbon Control on Soil Carbon Dynamics Across a Successional Gradient, Ecosystems, 14, 710-719, 2011.

Miller, R. and Jastrow, J.: Mycorrhizal fungi influence soil structure, in: Arbuscular mycorrhizas: physiology and function, Springer, Dordrecht, the Netherlands, 2000.

Murphy, C. J., Baggs, E. M., Morley, N., Wall, D. P., and Paterson, E.: Rhizosphere priming can promote mobilisation of $\mathrm{N}$ rich compounds from soil organic matter, Soil Biol. Biochem., 81, 236-243, 2015.

Nagahashi, G., Douds Jr., D. D., and Abney, G. D.: Phosphorus amendment inhibits hyphal branching of the VAM fungus Gigaspora margarita directly and indirectly through its effect on root exudation, Mycorrhiza, 6, 403-408, 1996.

Nottingham, A. T., Turner, B. L., Stott, A. W., and Tanner, E. V.: Nitrogen and phosphorus constrain labile and stable carbon turnover in lowland tropical forest soils, Soil Biol. Biochem., 80, 26-33, 2015.

Pearson, J. N. and Jakobsen, I.: The relative contribution of hyphae and roots to phosphorus uptake by arbuscular mycorrhizal plants, measured by dual labelling with ${ }^{32} \mathrm{P}$ and ${ }^{33} \mathrm{P}$, New Phytol., 124, 489-494, 1993.

Poeplau, C., Don, A., Vesterdal, L., Leifeld, J., Van Wesemael, B., Schumacher, J., and Gensior, A.: Temporal dynamics of soil organic carbon after land-use change in the temperate zone - carbon response functions as a model approach, Glob. Change Biol., 17, 2415-2427, 2011.

Ramirez, K. S., Craine, J. M., and Fierer, N.: Consistent effects of nitrogen amendments on soil microbial communities and processes across biomes, Glob. Change Biol., 18, 1918-1927, 2012.

Reed, S., Vitousek, P., and Cleveland, C.: Are patterns in nutrient limitation belowground consistent with those aboveground: results from a 4 million year chronosequence, Biogeochemistry, 106, 323-336, 2011.

Rillig, M., Wright, S., Nichols, K., Schmidt, W., and Torn, M.: Large contribution of arbuscular mycorrhizal fungi to soil carbon pools in tropical forest soils, Plant Soil, 233, 167-177, 2001.
Schimel, J. P. and Weintraub, M. N.: The implications of exoenzyme activity on microbial carbon and nitrogen limitation in soil: a theoretical model, Soil Biol. Biochem., 35, 549-563, 2003.

Shao, X.-H. and Zheng, J.-W.: Soil Organic Carbon, Black Carbon, and Enzyme Activity Under Long-Term Fertilization, Journal of Integrative Agriculture, 13, 517-524, 2014.

Simonsson, M., Hillier, S., and Öborn, I.: Changes in clay minerals and potassium fixation capacity as a result of release and fixation of potassium in long-term field experiments, Geoderma, 151, 109-120, 2009.

Sinsabaugh, R. L. and Moorhead, D. L.: Resource allocation to extracellular enzyme production: A model for nitrogen and phosphorus control of litter decomposition, Soil Biol. Biochem., 26, 1305-1311, 1994.

Strickland, M. S., Callaham Jr., M. A., Davies, C. A., Lauber, C. L., Ramirez, K., Richter Jr., D. D., Fierer, N., and Bradford, M. A.: Rates of in situ carbon mineralization in relation to landuse, microbial community and edaphic characteristics, Soil Biol. Biochem., 42, 260-269, 2010.

Van Cleve, K. and Moore, T. A.: Cumulative Effects of Nitrogen, Phosphorus, and Potassium Fertilizer Additions on Soil Respiration, pH, and Organic Matter Content, Soil Sci. Soc. Am. J., 42, 121-124, 1978.

Welbank, P. J., Gibb, M. J., Taylor, P. J., and Williams, E. D.: Root growth of cereal crops, Ann. Rep. Roth. Exp. Sta., 26-66, 1973.

Williams, A., Börjesson, G., and Hedlund, K.: The effects of 55 years of different inorganic fertiliser regimes on soil properties and microbial community composition, Soil Biol. Biochem., 67, 41-46, 2013.

Wilson, J. B.: A review of evidence on the control of shoot: root ratio, in relation to models, Ann. Bot., 61, 433-449, 1988.

Wyngaard, N., Echeverría, H. E., Rozas, H. R. S., and Divito, G. A.: Fertilization and tillage effects on soil properties and maize yield in a Southern Pampas Argiudoll, Soil Till. Res., 119, 22 30, 2012.

Yan, X., Zhou, H., Zhu, Q. H., Wang, X. F., Zhang, Y. Z., Yu, X. C., and Peng, X.: Carbon sequestration efficiency in paddy soil and upland soil under long-term fertilization in southern China, Soil Till. Res., 130, 42-51, 2013.

Zhengchao, Z., Zhuoting, G., Zhouping, S., and Fuping, Z.: Effects of long-term repeated mineral and organic fertilizer applications on soil organic carbon and total nitrogen in a semi-arid cropland, Eur. J. Agron., 45, 20-26, 2013.

Zhu, P., Ren, J., Wang, L., Zhang, X., Yang, X., and MacTavish, D.: Long-term fertilization impacts on corn yields and soil organic matter on a clay-loam soil in Northeast China, J. Plant Nutr. Soil Sc., 170, 219-223, 2007. 